\title{
Analisis Faktor-Faktor Yang Mempengaruhi Perilaku Disfungsional Auditor
}

\author{
Melinda Limanto 1 \\ I Made Sukartha ${ }^{2}$ \\ ${ }^{1,2}$ Fakultas Ekonomi dan Bisnis Universitas Udayana (Unud), Bali, Indonesia \\ e-mail:melinda_limanto@yahoo.co.id
}

\begin{abstract}
ABSTRAK
Penelitian ini bertujuan memperoleh bukti empiris pengaruh tekanan anggaran waktu, sifat machiavellian, locus of control internal, dan komitmen organisasi pada perilaku disfungsional auditor. Perilaku menyimpang auditor merupakan perilaku auditor yang mengurangi kualitas audit dan menyebabkan kegagalan proses audit. Penelitian dilakukan di BPKP RI Perwakilan Provinsi Bali tahun 2019. Responden dalam penelitian ini ditentukan menggunakan metode sampel jenuh. Pengumpulan data menggunakan metode penyebaran kuesioner. Uji regresi linear berganda digunakan sebagai teknik analisis data dalam penelitian ini. Hasil dari penelitian ini menunjukkan tekanan anggaran waktu, dan sifat machiavellian berpengaruh positif pada perilaku disfungsional auditor. Variabel locus of control internal, dan komitmen organisasi berpengaruh negatif pada perilaku disfungsional auditor.
\end{abstract}

Kata Kunci: Disfungsional, machiavellian, kontrol internal, komitmen.

\begin{abstract}
This study aims to obtain empirical evidence of the influence of time budger pressure, machiavellian, internal locus of control, and organizational comitment on auditor's dysfungsional behavior. Auditor's dysfungsional behavior is an behavior of auditor that reduces audit quality and causes the audit process to fail. The study was conducted at the RI BPKP Representative of Bali Province in 2019. Respondents in this study were determined using the saturated sample method. Data collection using the questionnaire method. The data analysis technique used is multiple linear regression. The results showed time budget pressures, and machiavellian traits had a positive effect on auditor dysfunctional behavior. Internal locus of control variables, and organizational commitment negatively affect auditor dysfunctional behavior.
\end{abstract}

Keywords: Dysfungsional, machiavellian, internal control, comitment

\section{PENDAHULUAN}

Pembangunan nasional telah menjadi salah satu fokus utama dari Pemerintah Indonesia. Pembangunan nasional dapat ditingkatkan dan berjalan lancar, apabila pengelolaan perekonomian negara dilakukan dengan baik. Lembaga pengawas internal pemerintah Indonesia adalah Badan Pengawasan Keuangan dan Pembangunan (BPKP). Lembaga tersebut berperan dalam melakukan pengawasan terhadap keuangan negara/daerah serta pembangunan nasional. Kualitas dari audit 
yang dilakukan oleh auditor dapat dilihat dari kecenderungan mereka melaporkan kekeliruan yang terdapat dalam laporan keuangan sesuai dengan hasil temuannya (Deangelo, 1981) Hal inilah yang membuat tugas dan wewenang BPKP menjadi sangat penting dalam upaya mewujudkan akuntabilitas negara dan pemerintah daerah.

Seorang auditor saat melakukan praktik audit tidak jarang berhadapan dengan situasi yang mampu menyebabkan kualitas audit menurun. Masalah keperilakuan merupakan suatu masalah yang tidak terlepas dari kegiatan auditor, seperti misalnya seorang auditor kemungkinan melakukan penyimpangan perilaku (dysfunctional behavior) dalam melakukan kegiatan audit, sehingga hal ini dapat menyebabkan menurunya kualitas audit. Perilaku meyimpang yang kemungkinan dilakukan oleh auditor diantaranya waktu pelaksanaan audit yang tidak sesuai (underreporting of time), pemberhentian prosedur dalam kegiatan audit (premature sign-off audit procedures), beberapa prosedur audit yang diganti atau bukti yang terkumpul belum cukup untuk melakukan proses audit (altering/replacement audit process atau gathering unsufficient evidence) menurut Otley dan Pierce (dalam Devi, 2017).

Fenomena penyimpangan perilaku auditor sempat menjadi perbincangan hangat. Salah satunya adalah penyalahgunaan anggaran join audit pangawasan dan pemeriksaan sebesar Rp 48 juta dalam kegiatan wasrik sertifikasi guru (sergu) di Inspektorat IV Kemendikbud oleh mantan Irjen Kemendikbud Mohammad Sofyan. Sisa anggaran sebesari Rp 200 juta justru dibagikan kepada peserta termasuk ke beberapa auditor BPKP (www.detik.com, diakses tanggal 12 Juli 
2018). Selain itu, pemalsuan dokumen diduga dilakukan oleh auditor BPKP dalam melaksanakan proses audit di Badang Pengawas Pemilu Jawa Timur, sebab auditor mengalami tekanan anggaran waktu, sehingga dalam pemeriksaan auditor tidak melaksanakan proses audit sesuai dengan Standar Operasional Prosedur (news.detik.com).

Perilaku disfungsional auditor salah satunya dapat disebabkan karena adanya tekanan anggaran waktu. Tekanan anggaran waktu merujuk pada kurangnya waktu yang ada saat pelaksanaan proses audit mengarah pada yang disebabkan oleh kurangnya waktu yang dimiliki (DeZoort dan Lord, 1997). Tekanan dalam menyelesaikan tugas dan kurangnya waktu yang diberikan menyebabkan auditor mengalami kebingungan (Cook dan Kelley, 1988). Wintari, dkk., 2015 menyebutkan tekanan anggaran waktu merupakan salah satu faktor utama yang menyebabkan terjadinya penurunan kualitas audit dan kinerja auditor. Penelitian Roni (2013) menyatakan bahwa time budget pressure berpengaruh signifikan positif terhadap perilaku disfungsional auditor.

Sifat Machiavellian merupakan sifat yang negatif hal ini dikarenakan individu menganggap remeh integritas dan kejujuran dalam melaksanakan tugasnya (Devi, 2017). Menghalalkan segala cara untuk mencapai sesuai yang diinginkan merupakan ciri khas dari sifat ini. Usmany, 2017 serta Devi dan Ramantha (2017) menunjukkan pengaruh positif dan signifikan yang disebabkan oleh sifat machiavellian pada perilaku disfungsional.

Locus of control internal menyebabkan auditor merasa bahwa sesuatu yang terjadi pada dirinya dikarenakan oleh dirinya sendiri, hal itu kemudian membuat 
mereka untuk berkinerja dengan maksimal. Daft (2011) berpendapat bahwa individu yang memiliki locus of control internal memikul beban utama dalam dirinya sendiri, dan hal yang dialami dipengaruhi oleh perilakunya sendiri. Hasil penelitian Hariani dan Ahmad (2017) yang menyatakan locus of control berpengaruh positif pada penerimaan penyimpangan perilaku dalam audit.

Seorang auditor yang memiliki komitmen tinggi akan berusaha keras dan akan memiliki kinerja yang lebih baik dibandingkan dengan auditor yang justru kurang memiliki komitmen (Basudewa \& Merkusiwati, 2015). Penelitian Triono dkk. (2012) menunjukkan komitmen organisasi berpengaruh negatif pada penerimaan perilaku disfungsional audit. Badan Pengawasan Keuangan dan Pembangunan (BPKP) Provinsi Bali merupakan salah satu lembaga penting yang menunjang perekonomian pemerintah daerah Bali. Lembaga ini melakukan pengawasan terhadap kinerja pemerintah daerah Bali.

Fenomena tersebut melatarbelakangi peneliti untuk melakukan penelitian terkait tekanan anggaran waktu, sifat machiavellian, locus of control internal, dan komitmen organisasi yang mempengaruhi perilaku disfungsional auditor di BPKP RI Perwakilan Provinsi Bali. Penelitian ini bertujuan untuk memperoleh bukti empiris mengenai pengaruh tekanan anggaran waktu, sifat machiavellian, locus of control internal, dan komitmen organisasi pada perilaku disfungsional auditor. Secara teoritis penelitian ini berguna untuk mengkonfirmasi teori atribusi mengenai cara seseorang dalam menginterpretasikan suatu peristiwa, alasan, atau sebab perilakunya. Secara praktis penelitian ini dapat memberikan pengetahuan 
tambahan kepada mahasiswa maupun masyarakat umum mengenai faktor-faktor yang mungkin menjadi penyebab adanya perilaku disfungsional auditor.

Teori Atribusi memberikan penjelasan mengenai cara seseorang dalam menginterpretasikan alasan suatu peristiwa terjadi, atau penyebab terjadinya peristiwa tersebut. Freitz Heider tahun 1958 dengan argumentasi bahwa ada dua hal yang menentukan perilaku seseorang, yakni kekuatan internal (internal force) yaitu kekuatan dalam dirinya, dan kekuatan eksternal (external force) yaitu kekuatan dari luar dirinya (Lubis, 2010).

Tekanan anggaran waktu menuntut auditor untuk melakukan efisiensi pada waktu yang telah ditetapkan, atau dalam kata lain melaukan pembatasan terhadap waktu yang telah dijadwalkan (Sososutiksno, 2010). Pembatasan waktu dalam proses audit dengan tuntutan laporan yang berkualitas merupakan tantangan sendiri bagi auditor. Kondisi yang tertekan oleh waktu menyebabkan auditor kemngkinan berperilaku menyimpang, misalnya melakukan prematur sign off. Tingginya tekanan anggaran waktu mendorong auditor untuk melakukan perilaku disfungsional (Suprianto, 2009).

Sifat Machiavellian adalah suatu kepribadian individu yang melakukan cara apapun dmei mencapai keinginannya. Individu yang memiliki sifat tersebut berusaha memanfaatkan keadaan untuk memperoleh keuntungan pribadi dan cenderung untuk tidak patuh pada peraturan (Ghosh dan Crain, 1996). Sifat Machiavellian yang tinggi membuat seseorang menggunakan perilaku yang manipulatif, persuasif, dan melakukan kecurangan dalam mencapai tujuan akhir (Bass, 1999). 
Locus of control internal menunjukkan kepercayaan seseorang terkait bagaimana perbuatan atau tindakannya berpengaruh pada keberhasilan atau kegagalan yang terjadi dalam dirinya. Rotter (1990:489) menyatakan locus of control internal dapat menjadi sebuah pengendalian internal dari kepribadian, yaitu apapun yang terjadi dalam dirinya dapat dikendalikan oleh dirinya sendiri pula. Locus of control internal dapat menjadi sebuat batasan bagi individu untuk melakukan tindakan yang tidak benar.

Komitmen organisasi memperlihatkan keinginan untuk bergabung dan terlibat dalam suatu organisasi, rasa kemauan yang tinggi untuk berusaha keras bagi organisasi, serta rasa keinginan yang tinggi untuk tetap bertahan dalam organisasi merupakan cara menilai seseorang terhadap organisasi dalam hal loyalitas, identifikasi, dan keterlibatan. Seseorang yang memiliki komitmen organisasi akan bekerja lebih baik dibandingkan dengan seseorang yang tidak memiliki komitmen.

Teori atribusi mencoba mencari penjelasan mengenai apakah perilaku seseorang disebabkan oleh faktor dispositional attributions (internal) atau situational attributions (eksternal) (Luthans, 2006:154). Salah satu faktor eksternal adalah tekanan anggaran waktu. Salah satu factor penghambat kualitas kinerja auditor adalah tuntutan waktu yang membuat mereka cenderung tergesagesa dalam berkinerja. Penelitian yang dilakukan McNamara \& Liyanarachchi (2008) menemukan bahwa auditor di New Zealand percaya jika dihadapkan dengan anggaran waktu yang sulit, tidak sedikit auditor sering bekerja pada waktu pribadi dan dalam kendala waktu yang parah auditor akan melakukan langkah- 
langkah yang disfungsional untuk menangani tekanan tersebut.

Tekanan anggaran waktu dalam teori atribusi disebabkan oleh faktor dari luar diri (situational attribution). Pembatasan waktu dalam menyelesaikan audit menyebabkan auditor tidak dapat menyelesaikan tugasnya sesuai dengan standar operasional prosedur. Hal ini akan menyebabkan auditor cenderung melakukan perilaku disfungsional audit untuk memenuhi anggaran waktu yang diberikan. Tekanan waktu yang diberikan menimbulkan kecenderungan auditor untuk berperilaku menyimpang.

Berdasarkan uraian tersebut, maka hipotesis yang dikembangkan dalam penelitian ini sebagai berikut.

$\mathrm{H}_{1}$ : Tekanan anggaran waktu berpengaruh positif pada perilaku disfungsional auditor.

Robbins dan Judge (2015:172) menyatakan teori atribusi adalah perilaku seseorang yang disebabkan oleh faktor internal atau faktor eksternal. Teori atribusi memberikan jawaban mengenai cara dalam menentukan latar belakang dari perilaku seseorang. Sifat machavellian yang tinggi membuat individu cenderung melakukan cara apapun untuk memperoleh keuntungan pribadi, termasuk tidak mengindahkan peraturan yang ada. Penelitian Yuli (2015) memperoleh hasil bahwa sifat machiavellian memiliki pengaruh positif terhadap perilaku menyimpang auditor. Sifat Machiavellian yang tinggi mengarah pada tingginya perilaku meyimpang yang dilakukannya, begitu pula sebaliknya, sifat Machiavellian yang rendah akan mengarah pada rendahnya kecenderungan auditor untuk berperilaku menyimpang. Dalam teori atribusi, sifat machiavellian disebabkan oleh faktor dari luar diri (situational attribution) karena penyebab luar 
tersebut lebih mengacu kepada situasi yang mempengaruhi upaya dalam mencapai reward.

Berdasarkan hal tersebut maka hipotesis yang dikembangkan dalam penelitian ini sebagai berikut.

$\mathrm{H}_{2}$ : Sifat Machiavellian berpengaruh positif pada perilaku disfungsional auditor.

Locus of control internal yang tinggi dalam diri seseorang, mebuat mereka percaya bahwa semua yang terjadi dalam dirinya disebabkan oleh dirinya sendiri. Penelitian Rustiarini, 2014 menemukan bahwa locus of control internal memiliki pengaruh yang negatif terhadap perilaku disfungsional auditor. Dalam teori atribusi, locus of control internal disebabkan oleh faktor yang berasal dari dalam diri atau faktor internal yaitu penyebab yang berada dibawah kendali pribadi individu tersebut. Seseorang yang memiliki locus of control internal meyakini bahwa suatu kejadian yang dialaminya adalah berasal dari usaha mereka sendiri atau dalam kontrol kendalinya. Auditor yang memiliki locus of control internal tinggi merasa semakin tertantang untuk meningkat kinerja mereka, dan mampu mengendalikan stress dengan lebih baik.

Berdasarkan uraian di atas, hipotesis yang dikembangkan adalah.

$\mathrm{H}_{3}$ : Locus of control internal berpengaruh negatif pada perilaku disfungsional auditor.

Komitmen organisais menunjukkan keinginan individu untuk mempertahankan diri dalam bersosialisasi pada suatu organisasi, bergabung bersama dengan anggota yang lain dalam menjalankan operasional organisasi, dan mengabdikan dirinya dalam organisasi tempatnya berkomitmen. Penelitian oleh 
Otley dan Pierce (1996) menemukan bahwa terdapat hubungan yang signifikan antara komitmen organisasi dengan perilaku audit disfungsional. Berdasarkan teori atribusi, komitmen organisasi disebabkan oleh faktor internal (dispositional attributions) yaitu berasal dari dalam diri individu yang bersangkutan seperti keperibadian, persepsi diri, kemampuan, motivasi dan usaha.

Berdasarkan uraian di atas, hipotesis yang dikembangkan adalah.

$\mathrm{H}_{4} \quad$ : Komitmen Organisasi berpengaruh negatif pada perilaku disfungsional auditor.

\section{METODE PENELITIAN}

Menurut Sugiyono (2017:56) metode penelitian kuantitatif adalah metode penelitian yang yang digunakan untuk meneliti populasi atau sampel tertentu yang bertujuan untuk menguji hipotesis yang telah ditetapkan dengan menggunakan data yang telah dikumpulkan. Berikut merupakan rancangan desain penelitian.

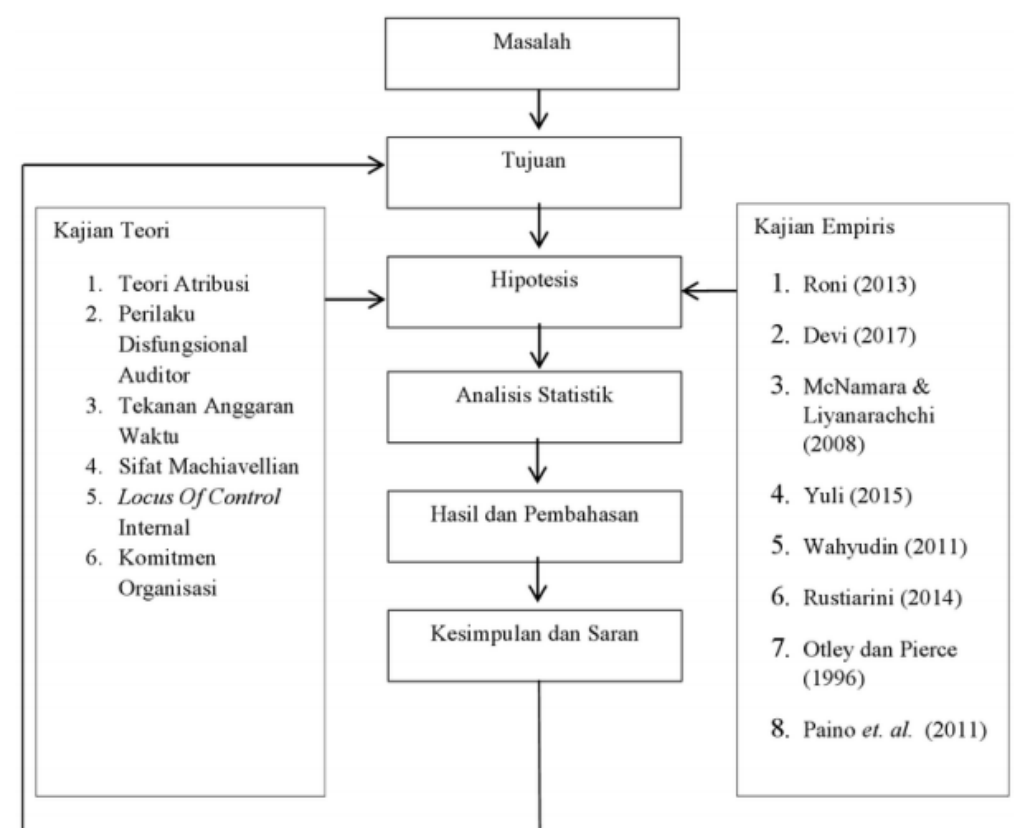

Gambar 1. Desain Penelitian

Sumber : Data diolah, 2018 
Penelitian dilakukan di Jalan Kapten Tantular, Denpasar, Bali dan ruang lingkupnya adalah Badan Pengawasan Keuangan dan Pembangunan (BPKP) Provinsi Bali yang menjadi anggota auditor. Alasan pemilihan lokasi adalah karena BPKP merupakan salah satu badan yang efektif dalam melakukan pengawasan dan monitoring terhadap kinerja pemerintah daerah. Pemerintah Daerah Provinsi Bali memperoleh masukan dana yang cukup besar dari berbagai bidang ekonomi, sehingga melakukan pengawasan terhadap organisasi pemerintah sangat diperlukan. Hal tersebut menjadi salah satu pemicu semakin besarnya kemungkinan tindakan perilaku disfungsional auditor, sehingga BPKP merupakan badan strategis dalam menjalankan fungsi pengawasan terhadap kinerja pemerintah daerah. Objek dalam penelitian ini adalah perilaku disfungsional auditor yang dialami anggota auditor di BPKP RI Perwakilan Provinsi Bali yang dipengaruhi tekanan anggaran waktu, sifat machiavellian, locus of control internal, dan komitmen organisasi. Variabel dependen dalam penelitian ini adalah perilaku disfungsional auditor (Y), sedangkan variabel independennya antara lain tekanan anggaran waktu $\left(\mathrm{X}_{1}\right)$, sifat machiavellian $\left(\mathrm{X}_{2}\right)$, locus of control internal $\left(\mathrm{X}_{3}\right)$, dan komitmen organisasi $\left(\mathrm{X}_{4}\right)$.

Populasi dalam penelitian ini adalah seluruh fungsional auditor yang bekerja di BPKP RI Perwakilan Provinsi Bali tahun 2019 berjumlah 74 auditor, menggunakan metode sampel jenuh sehingga semua populasi digunakan sebagai sampel dalam penelitian ini. Metode pengumpulan data menggunakan kuesioner dengan dengan skala Likert yang terdiri atas 5 pilihan jawaban, yaitu poin 5 Sangat Setuju (SS), 4 Setuju (S), poin 3 Ragu-ragu (R), poin 2 Kurang Setuju 
(KS), dan poin 1 Sangat Tidak Setuju (STS). Teknik analisis data yang digunakan dalam penelitian ini adalah analisis regresi linear berganda, dengan tahapan (1) uji statistik deskriptif, (2) uji asumsi klasik, (3) analisis regresi linear berganda, (4) pengujian hipotesis meliputi uji koefisien determinasi $\left(\mathrm{R}^{2}\right)$, uji kelayakan model (uji F), dan uji hipotesis (uji t). Model regresi berganda dirumuskan dalam bentuk sebagai berikut.

$$
\mathrm{Y}=\alpha+\beta_{1} \mathrm{X}_{1}+\beta_{2} \mathrm{X}_{2}+\beta_{3} \mathrm{X}_{3}+\mathrm{e}+\ldots
$$

\section{Keterangan :}

$$
\begin{array}{ll}
\mathrm{Y} & =\text { Perilaku Disfungsional Auditor } \\
\alpha & =\text { Konstanta } \\
\beta_{1} \cdot \beta_{2} \cdot \beta_{3} \cdot \beta_{4}, & =\text { Koefisien Regresi Variabel X1, X2, dan X3 } \\
\mathrm{X}_{1} & =\text { Tekanan Anggaran Waktu } \\
\mathrm{X}_{2} & =\text { Kepemimpinan Sifat Machiavellian } \\
\mathrm{X}_{3} & =\text { Locus of Control Internal } \\
\mathrm{X}_{4} & =\text { Komitmen Organisasi } \\
\mathrm{e} & =\text { Eror }
\end{array}
$$

\section{HASIL DAN PEMBAHASAN}

Badan Pengawas Keuangan dan Pembangunan (BPKP) merupakan lembaga yang berada di bawah presiden dan bertanggung jawab langsung kepada presiden, serta merupakan Lembaga Pemerintah Non Departemen (LPND). Dasar hukum pembentukan lembaga ini adalah Keputusan Presiden Nomor 31 Tahun 1983 tentang BPKP karena perlunya badan atau lembaga yang bertugas untuk memberikan pengawasan independen tanpa kemungkinan tekanan dari organisasi lain yang diperiksanya.

Penelitian ini dilakukan untuk mengetahui secara empiris pengaruh tekanan anggaran waktu, sifat machiavellian, locuf of control internal, dan komitmen 
organisasi pada perilaku disfungsional auditor di BPKP RI Perwakilan Provinsi Bali. Pengumpulan data digunakan dengan menyebarkan kuesioner secara langsung ke BPKP RI Perwakilan Provinsi Bali, yang berjumlah sebanyak 74 kuesioner. Kuesioner yang tidak kembali sebanyak 19 kuesioner dan yang kembali sebanyak 55 kuesioner. Ringkasan pengiriman serta pengembalian kuesioner disajikan dalam tabel 1 berikut.

Tabel 1.

Ringkasan Pengiriman dan Pengembalian Kuesioner

\begin{tabular}{lcc}
\hline \multicolumn{1}{c}{ Kuesioner } & Jumlah & Persentase (\%) \\
\hline Kuesioner dikirim & 74 & 100 \\
Kuesioner kembali & 55 & 74,32 \\
Kuesioner tidak kembali & 19 & 25,68 \\
Kuesioner yang gugur & 0 & 0 \\
Kuesioner yang digunakan & 55 & 74,32 \\
\hline Sumber $:$ Data diolah, 2018 & &
\end{tabular}

Berdasarkan tabel 1 menunjukkan bahwa kuesioner yang tersebar ke responden sebanyak 74 kuesioner, jumlah kuesioner yang dikembalikan adalah 55 kuesioner (74\%) sedangkan sebanyak 19 kuesioner tidak kembali karena kesibukan auditor maupun karena hilang. Berdasarkan kondisi tersebut jumlah kuesioner yang layak digunakan untuk dianalisis sebanyak 55 kuesioner.

Uji validitas digunakan untuk mengukur sah atau tidaknya suatu kuesioner. Apabila nilai pearson correlation $>0,30$ maka instrumen tersebut dinyatakan valid (Sugiyono 2017:178). Hasil uji validitas disajikan pada Tabel 2.

Tabel 2.

Hasil Uji Validitas

\begin{tabular}{lcccc}
\hline No. & Variabel & Item & $\begin{array}{c}\text { Pearson } \\
\text { Correlation }\end{array}$ & Keterangan \\
\hline 1 & Tekanan Anggaran Waktu (X1) & $\mathrm{X}_{1} \cdot 1$ & 0,515 & Valid \\
& & $\mathrm{X}_{1} \cdot 2$ & 0,546 & Valid \\
& & $\mathrm{X}_{1} \cdot 3$ & 0,477 & Valid \\
& & $\mathrm{X}_{1} \cdot 4$ & 0,520 & Valid \\
& & $\mathrm{X}_{1} \cdot 5$ & 0,432 & Valid \\
& & $\mathrm{X}_{1} .6$ & 0,429 & Valid \\
2 & Sifat Machiavellian (X2) & $\mathrm{X}_{2} \cdot 1$ & 0,604 & Valid \\
\hline
\end{tabular}


ISSN: 2302-8556

\begin{tabular}{|c|c|c|c|c|}
\hline & & $\mathrm{X}_{2} .2$ & 0,811 & Valid \\
\hline & & $\mathrm{X}_{2} .3$ & 0,863 & Valid \\
\hline & & $\mathrm{X}_{2} .4$ & 0,812 & Valid \\
\hline & & $\mathrm{X}_{2} .5$ & 0,782 & Valid \\
\hline & & $\mathrm{X}_{2} .6$ & 0,706 & Valid \\
\hline & & $\mathrm{X}_{2.7}$ & 0,773 & Valid \\
\hline & & $\mathrm{X}_{2} .8$ & 0,802 & Valid \\
\hline 3 & Locus of Control Internal (X3) & $\mathrm{X}_{3} .1$ & 0,493 & Valid \\
\hline & & $\mathrm{X}_{3} .2$ & 0,907 & Valid \\
\hline & & $\mathrm{X}_{3.3}$ & 0,786 & Valid \\
\hline & & $\mathrm{X}_{3} .4$ & 0,879 & Valid \\
\hline & & $\mathrm{X}_{3.5}$ & 0,830 & Valid \\
\hline & & $\mathrm{X}_{3} .6$ & 0,820 & Valid \\
\hline 4 & Komitmen Organisasi (X4) & $\mathrm{X}_{4.1}$ & 0,689 & Valid \\
\hline & & $\mathrm{X}_{4} \cdot 2$ & 0,642 & Valid \\
\hline & & $\mathrm{X}_{4.3}$ & 0,647 & Valid \\
\hline & & $\mathrm{X}_{4} \cdot 4$ & 0,800 & Valid \\
\hline & & $\mathrm{X}_{4.5}$ & 0,834 & Valid \\
\hline & & $\mathrm{X}_{4} \cdot 6$ & 0,785 & Valid \\
\hline & & $X_{4.7}$ & 0,854 & Valid \\
\hline & & $\mathrm{X}_{4} .8$ & 0,774 & Valid \\
\hline & & $\mathrm{X}_{4} .9$ & 0,606 & Valid \\
\hline 4 & $\begin{array}{l}\text { Perilaku Disfungsional Auditor } \\
\text { (Y) }\end{array}$ & Y.1 & 0,797 & Valid \\
\hline & & Y.2 & 0,812 & Valid \\
\hline & & Y.3 & 0,775 & Valid \\
\hline & & Y.4 & 0,747 & Valid \\
\hline & & Y.5 & 0,853 & Valid \\
\hline & & Y.6 & 0,844 & Valid \\
\hline & & Y.7 & 0,728 & Valid \\
\hline & & Y.8 & 0,773 & Valid \\
\hline & & Y.9 & 0,742 & Valid \\
\hline & & Y.10 & 0,887 & Valid \\
\hline & & Y.11 & 0,815 & Valid \\
\hline
\end{tabular}

Sumber: Data diolah, 2018

Uji reliabilitas bertujuan untuk mengetahui sejauh mana alat ukur dapat dipercaya atau dapat diandalkan. Suatu instrumen dikatakan reliabel apabila nilai cronbach's alpha lebih dari 0,70 (Ghozali, 2013:47). Hasil uji reliabilitas disajikan dalam tabel 3 berikut.

Tabel 3.

Hasil Uji Reliabilitas

\begin{tabular}{lcc}
\hline \multicolumn{1}{c}{ Variabel } & Koefisien Alpha Cronbach & Keterangan \\
\hline Tekanan Anggaran Waktu (X1) & 0,740 & Reliabel \\
Sifat Machiavellian (X2) & 0,896 & Reliabel \\
Locus of Control Internal (X3) & 0,883 & Reliabel \\
Komitmen Organisasi (X4) & 0,894 & Reliabel \\
Perilaku Disfungsional Auditor (Y) & 0,941 & Reliabel \\
\hline
\end{tabular}

Sumber : Data diolah, 2018 
Berdasarkan tabel 4 dapat dilihat bahwa kelima variabel penelitian ini memiliki koefisien cronbach's alpha yang lebih besar dari angka 0,60. Hal ini menunjukkan bahwa semua pernyataan dalam kuesioner penelitian ini reliabel dan dapat digunakan.

Statistik deskriptif bertujuan untuk mendeskripsikan data menjadi sebuah informasi yang mudah dipahami. Hasil analisis statistik deskriptif tersaji pada tabel 4 berikut.

Tabel 4.

Hasil Analisis Statistik Deskriptif

\begin{tabular}{lccccc}
\hline \multicolumn{1}{c}{ Variabel } & N & Minimum & Maksimum & $\begin{array}{c}\text { Rata- } \\
\text { rata }\end{array}$ & $\begin{array}{c}\text { Standar } \\
\text { Deviasi }\end{array}$ \\
\hline Tekanan Anggaran Waktu (X1) & 55 & 13 & 24 & 19,56 & 2,025 \\
Sifat Machiavellian (X2) & 55 & 11 & 38 & 30,51 & 6,426 \\
Locus Of Control Internal (X3) & 55 & 7 & 30 & 21,40 & 5,503 \\
Komitmen Organisasi (X4) & 55 & 26 & 45 & 36,55 & 5,210 \\
Perilaku Disfungsional Auditor (Y) & 55 & 15 & 55 & 38,76 & 10,066 \\
\hline Sumber : Data diolah, 2018 & & & & &
\end{tabular}

Berdasarkan Tabel 4 diketahui deskripsi umum hasil penelitian sebagai berikut. Variabel perilaku disfungsional auditor (Y) memiliki nilai minimum sebesar 15, nilai maksimum sebesar 55 dengan nilai rata-rata sebesar 38,76. Nilai standar deviasi variabel perilaku disfungsional auditor adalah sebesar 10,066. Nilai rata-rata sebesar 38,76 menunjukkan perilaku disfungsional auditor sedang yaitu berada dalam kisaran $>31-39$.

Variabel tekanan anggaran waktu $\left(\mathrm{X}_{1}\right)$ memiliki nilai minimum sebesar 13, nilai maksimum sebesar 24 dengan nilai rata-rata sebesar 19,56. Nilai standar deviasi variabel tekanan anggaran waktu adalah sebesar 2,025. Nilai rata-rata sebesar 19,56 menunjukkan tekanan anggaran waktu tinggi yaitu berada dalam kisaran >19,6-21,8. Variabel sifat machiavellian $\left(X_{2}\right)$ memiliki nilai minimum 
sebesar 11, nilai maksimum sebesar 38 dengan nilai rata-rata sebesar 30,51. Nilai standar deviasi variabel sifat machiavellian adalah sebesar 6,426. Nilai rata-rata sebesar 30,51 menunjukkan sifat machiavellian tinggi yaitu berada dalam kisaran $>27,2-32,6$. Variabel locus of control internal $\left(\mathrm{X}_{3}\right)$ memiliki nilai minimum sebesar 7, nilai maksimum sebesar 30 dengan nilai rata-rata sebesar 21,40. Nilai standar deviasi variabel locus of control internal adalah sebesar 5,503. Nilai ratarata sebesar 21,40 menunjukkan locus of control internal tinggi yaitu berada dalam kisaran $>20,8-25,4$. Variabel komitmen organisasi $\left(\mathrm{X}_{4}\right)$ memiliki nilai minimum sebesar 26, nilai maksimum sebesar 45 dengan nilai rata-rata sebesar 36,55. Nilai standar deviasi variabel komitmen organisasi adalah sebesar 5,210. Nilai rata-rata sebesar 36,55 menunjukkan komitmen organisasi sedang yaitu berada dalam kisaran $>33,6-37,4$.

Sebelum model regresi digunakan untuk menguji hipotesis, tentunya model tersebut bebas dari uji asumsi klasik. Uji normalitas bertujuan menguji apakah dalam model penelitian variabel terdistribusi secara normal atau tidak berdistribusi normal. Data dikatakan berdistribusi normal apabila koefisien Asymp. Sig. (2-tailed) lebih dari 0,05. Hasil pengujian normalitas disajikan dalam Tabel 5 berikut. 
Tabel 5.

Hasil Uji Normalitas Data

\begin{tabular}{|c|c|c|}
\hline & & Unstandardized Residual \\
\hline $\mathrm{N}$ & & 55 \\
\hline \multirow[t]{2}{*}{ Normal Parameters ${ }^{a, b}$} & Mean & OE-7 \\
\hline & Std. Deviation & 9.87802730 \\
\hline \multirow[t]{3}{*}{ Most Extreme Differences } & Absolute & .096 \\
\hline & Positive & .059 \\
\hline & Negative & -.096 \\
\hline Test Statistic & &, 061 \\
\hline Asymp. Sig. (2-tailed) & & , 200 \\
\hline
\end{tabular}

Berdasarkan hasil uji normalitas pada tabel 4.6 dapat dilihat bahwa nilai signifikansi sebesar $0,687(0,687>0,05)$ yang artinya residual model regresi berdistribusi normal.

Uji Multikoliniearitas bertujuan untuk menguji apakah pada model regresi ditemukan adanya korelasi antar variabel bebas, menggunakan nilai tolerance atau Variance Inflation Factor (VIF). Jika nilai tolerance lebih besar dari $10 \%$ atau VIF kurang dari 10, maka dapat dikatakan model regresi bebas dari gejala multikoliniearitas (Ghozali, 2016:105). Hasil pengujian multikolinieritas disajikan dalam Tabel 6.

Tabel 6.

Hasil Uji Multikolinieritas

\begin{tabular}{lccc}
\hline \multirow{2}{*}{ Model } & \multicolumn{2}{c}{ Collinearity Statistic } & \multirow{2}{*}{ Keterangan } \\
\cline { 2 - 3 } & Tolerance & VIF & Tidak ada multikolinieritas \\
Tekanan Anggaran Waktu (X1) & 0,924 & 1,083 & \\
Sifat Machiavellian (X2) & 0,876 & 1,142 & Tidak ada multikolinieritas \\
Locus Of Control Internal (X3) & 0,915 & 1,093 & Tidak ada multikolinieritas \\
Komitmen Organisasi (X4) & 0,930 & 1,076 & \\
\hline Sumber : Data diolah, 2018 & & &
\end{tabular}

Berdasarkan hasil uji multikolinearitas pada tabel 6 dapat dilihat bahwa nilai tolerance pada masing-masing variabel lebih besar dari 10\% dan VIF kurang dari 10. Hal ini menunjukkan model regresi terbebas dari multikolinearitas. 
Uji Heteroskedastisitas bertujuan untuk menguji apakah dalam model regresi terjadi ketidaksamaan varians dari residual satu pengamatan ke pengamatan lain yang dilakukan dengan uji Glejser. Hasil uji heteroskedastisitas disajikan dalam tabel 7 berikut.

Tabel 7.

Hasil Uji Heteroskedastisitas

\begin{tabular}{lcc}
\hline \multicolumn{1}{c}{ Variabel } & Sig. & Keterangan \\
\hline Tekanan Anggaran Waktu (X1) & 0,299 & Bebas Heteroskedastisitas \\
Sifat Machiavellian (X2) & 0,518 & Bebas Heteroskedastisitas \\
Locus Of Control Internal (X3) & 0,790 & Bebas Heteroskedastisitas \\
Komitmen Organisasi (X4) & 0,960 & Bebas Heteroskedastisitas \\
\hline
\end{tabular}
Sumber : Data diolah, 2018

Berdasarkan Tabel 7 dapat dilihat bahwa nilai signifikansi dari masingmasing variabel tersebut diatas 0,05 , yang artinya model regresi bebas dari gejala heteroskedastisitas.

Analisis Regresi Linear Berganda diolah dengan bantuan software SPSS for Windows dengan hasil yang dapat dilihat pada Tabel 8 berikut.

\section{Tabel 8.}

\section{Hasil Uji Regresi Linear Berganda}

\begin{tabular}{|c|c|c|c|c|c|}
\hline \multirow[t]{2}{*}{ Model } & \multicolumn{2}{|c|}{$\begin{array}{c}\text { Unstandardized } \\
\text { Coefficients }\end{array}$} & \multirow{2}{*}{$\begin{array}{c}\begin{array}{c}\text { Standardized } \\
\text { Coefficients }\end{array} \\
\text { Beta }\end{array}$} & \multirow[b]{2}{*}{$t$} & \multirow[b]{2}{*}{ Sig. } \\
\hline & $B$ & Std. Error & & & \\
\hline Constant & 4,442 & 0,951 & & 4,670 & 0,000 \\
\hline Tekanan Anggaran Waktu (X1) & 0,342 & 0,052 & 0,379 & 6,590 & 0,000 \\
\hline Sifat Machiavellian (X2) & 0,133 & 0,041 & 0,182 & 3,205 & 0,002 \\
\hline Locus Of Control Internal (X3) & $-0,281$ & 0,049 & $-0,360$ & $-5,756$ & 0,000 \\
\hline Komitmen Organisasi (X4) & $-0,165$ & 0,055 & $-0,142$ & $-3,021$ & 0,003 \\
\hline Adjusted $R^{2}$ & 0,724 & & & & \\
\hline F Hitung & 98,534 & & & & \\
\hline Sig. $F$ & 0,000 & & & & \\
\hline
\end{tabular}

Sumber : Data diolah, 2018

Sehingga persamaan garis regresi linear berganda adalah sebagai berikut.

$$
Y=4,442+0,342 X_{1}+0,133 X_{2}-0,281 X_{3}-0,165 X_{3}+e
$$


Berdasarkan model regresi tersebut, dapat diinterpretasikan sebagai berikut. Konstanta regresi $(\alpha)$ sebesar 4,442 menunjukkan bahwa apabila nilai tekanan anggaran waktu $\left(\mathrm{X}_{1}\right)$, sifat Machiavellian $\left(\mathrm{X}_{2}\right)$, locus of control internal $\left(\mathrm{X}_{3}\right)$, dan komitmen organisasi $\left(\mathrm{X}_{4}\right)$ sama dengan nol, maka nilai perilaku disfungsional auditor (Y) cenderung positif.

Koefisien regresi tekanan anggaran waktu $\left(\beta_{1}\right)$ memiliki tanda positif yang menunjukkan bahwa variabel tekanan anggaran waktu mempunyai hubungan positif pada perilaku disfungsional auditor. Dengan asumsi variabel lainnya konstan sementara tekanan anggaran waktu $\left(\mathrm{X}_{1}\right)$ meningkat, maka perilaku disfungsional auditor (Y) akan cenderung meningkat. Koefisien sifat machiavellian $\left(\beta_{2}\right)$ memiliki tanda positif yang menunjukkan bahwa variabel sifat machiavellian mempunyai hubungan positif pada perilaku disfungsional auditor. Dengan asumsi variabel lainnya konstan sementara sifat machiavellian $\left(\mathrm{X}_{2}\right)$ meningkat, maka perilaku disfungsional auditor (Y) akan cenderung meningkat. Koefisien locus of control internal $\left(\beta_{3}\right)$ memiliki tanda negatif yang menunjukkan bahwa variabel locus of control internal mempunyai hubungan negatif pada perilaku disfungsional auditor. Dengan asumsi variabel lainnya konstan sementara locus of control internal $\left(\mathrm{X}_{3}\right)$ meningkat, maka perilaku disfungsional auditor $(\mathrm{Y})$ akan cenderung menurun. Koefisien komitmen organisasi $\left(\beta_{4}\right)$ memiliki tanda negatif yang menunjukkan bahwa variabel komitmen organisasi mempunyai hubungan negatif pada perilaku disfungsional auditor. Dengan asumsi variabel lainnya konstan sementara komitmen organisasi $\left(\mathrm{X}_{4}\right)$ meningkat, maka perilaku disfungsional auditor (Y) akan cenderung menurun. 
Nilai dari adjusted $\mathrm{R}^{2}$ sebesar 0,724 atau 72,4 persen. Artinya sebesar 72,4 persen variansi perilaku disfungsional auditor dipengaruhi oleh tekanan anggaran waktu $\left(\mathrm{X}_{1}\right)$, sifat machiavellian $\left(\mathrm{X}_{2}\right)$, locus of control internal $\left(\mathrm{X}_{3}\right)$, dan komitmen organisasi $\left(\mathrm{X}_{4}\right)$ sedangkan sisanya sebesar 27,6 persen dipengaruhi oleh faktor lain yang tidak dimasukkan ke dalam model penelitian. Nilai signifikansi F adalah sebesar 0,000, kurang dari dari $0,05(\mathrm{~F}<\alpha)$ yang berarti variabel bebas yaitu tekanan anggaran waktu $\left(\mathrm{X}_{1}\right)$, sifat machiavellian $\left(\mathrm{X}_{2}\right)$, locus of control internal $\left(\mathrm{X}_{3}\right)$, dan komitmen organisasi $\left(\mathrm{X}_{4}\right)$ berpengaruh secara serempak atau bersamasama pada variabel terikat yaitu perilaku disfungsional auditor (Y).

Hasil penelitian menunjukkan bahwa nilai $\beta 1=0,342$ dengan tingkat signifikansi sebesar 0,000 kurang dari $\alpha=0,05$. Hal ini memiliki arti bahwa hipotesis 1 diterima, yaitu variabel tekanan anggaran waktu berpengaruh positif pada perilaku disfungsional auditor. Teori atribusi menyatakan bahwa tekanan anggaran waktu mempengaruhi perilaku disfungsional auditor yang ditandai dengan adanya pembatasan anggaran waktu dalam pelaksanaan audit, hal ini mengakibatkan auditor tertekan sehingga hasil audit cenderung tidak optimal. Tekanan inilah yang membuat auditor melakukan perilaku penyimpangan untuk mencapai tujuannya. Hasil penelitian ini sejalan dengan penelitian Roni (2013) dan Devi (2017) yang menyatakan bahwa tekanan anggaran waktu berpengaruh positif pada perilaku disfungsional auditor.

Hasil penelitian menunjukkan bahwa nilai $\beta 2=0,133$ dengan tingkat signifikansi sebesar 0,002 kurang dari $\alpha=0,05$. Hal ini memiliki arti bahwa hipotesis kedua diterima, yaitu variabel sifat machiavellian berpengaruh positif 
dan signifikan pada perilaku disfungsional auditor. Teori atribusi menyatakan sifat machiavellian disebabkan oleh faktor dari luar diri (situational attribution) karena penyebab luar tersebut lebih mengacu kepada situasi yang mempengaruhi upaya dalam mencapai reward. Seorang auditor cenderung akan melakukan tindakantindakan manipulasi untuk mencapai target yang diingikan. Hasil penelitian ini sejalan dengan penelitian Yuli (2015) dan Devi (2017) yang menyatakan bahwa sifat machiavellian berpengaruh positif dan signifikan pada perilaku disfungsional auditor. Untuk mencapai sesuatu yang diinginkan individu akan menghalakan segala cara demi tercapainya tujuan yang diinginkan.

Hasil penelitian menunjukkan bahwa nilai $\beta 3=-0,281$ dengan tingkat signifikansi sebesar 0,000 lebih kecil dari $\alpha=0,05$. Hal ini memiliki arti bahwa hipotesis ketiga diterima, yaitu variabel locus of control internal berpengaruh negarif pada perilaku disfungsional auditor. Teori atribusi menyatakan locus of control internal disebabkan oleh faktor internal yaitu pemicu yang berada dibawah kendali pribadi individu tersebut. Auditor yang memiliki locus of control internal yang tinggi cenderung percaya dengan hasil yang dicapai dari kemampuan dan usaha dalam diri auditor tersebut. Sehingga dalam melakukan pekerjaannya auditor tidak akan tergantung pada keberuntungan ataupun nasibnya, maka dari itu auditor dengan locus of control internal yang tinggi cenderung dapat menghadapi situasi sulit dalam pekerjaannya tanpa melakukan kecurangan dan akan meminimalisir terjadinya penerimaan penyimpangan perilaku dalam audit. Hasil penelitian ini sejalan dengan penelitian Wahyudin, dkk., 2011 dan Rustiarini (2014) yang menyatakan bahwa locuf of control internal berpengaruh negatif pada 
perilaku disfungsional auditor. Auditor yang memiliki locus of control internal tinggi mampu mengendalikan emosi yang ada dalam dirinya, dan tidak mentolerir adanya perilaku disfungsional.

Hasil penelitian menunjukkan bahwa nilai $\beta 4=-0,165$ dengan tingkat signifikansi sebesar 0,003 lebih kecil dari $\alpha=0,05$. Hal ini memiliki arti bahwa hipotesis keempat diterima, yaitu variabel komitmen organisasi berpengaruh negarif dan signifikan pada perilaku disfungsional auditor. Teori atribusi menyatakan komitmen organisasi disebabkan oleh faktor internal (dispositional attributions) yaitu berasal dari dalam diri individu yang bersangkutan seperti keperibadian, persepsi diri, kemampuan, motivasi dan usaha. Individu dengan komitmen organisasi yang tinggi akan memiliki keinginan agar organisasinya mencapai kesuksesan. Sehingga individu tersebut akan melakukan usaha yang keras dengan tujuan untuk tetap bertahan dalam organisasi tempat mereka bekerja dan memiliki tujuan agar organisasinya mencapai kesuksesan.

\section{SIMPULAN}

Tekanan anggaran waktu dan Sifat machiavellian berpengaruh positif pada perilaku disfungsional auditor. Hal ini dikarenakan tekanan anggaran waktu yang tinggi akan mengakibatkan auditor tertekan sehingga auditor cenderung akan melakukan penyimpangan dalam audit atau melakukan perilaku disfungsional untuk mencapai tujuannya, dan auditor yang memiliki sifat machiavellian yang tinggi cenderung akan melakukan perilaku disfungsional auditor. Locus of control internal dan komitmen organisasi berpengaruh negatif pada perilaku disfungsional 
auditor. Auditor yang memiliki locus of control internal tidak mudah menerima perilaku disfungsional audit karena mereka cenderung memiliki kemampuan untuk menghadapi ancaman-ancaman yang timbul serta berusaha memecahkan permasalahan dengan optimis. Komitmen organisasi yang tinggi dalam diri auditor cenderung membuat auditor tidak menerima perilaku disfungsional audit karena mereka akan berusaha keras dengan tujuan untuk tetap bertahan didalam organisasi dan memiliki tujuan agar organisasinya mencapai kesuksesan. Kepala Badan Pengawas Keuangan dan Pembangunan (BPKP) RI Perwakilan Provinsi Bali dalam menganggarkan alokasi waktu lebih realistis sesuai dengan kompleksitas audit yang diterima auditor agar tidak terjadi perilaku disfungsional auditor. Auditor juga perlu untuk diberikan pemahaman mengenai arti dari bekerja secara jujur tanpa memikirkan pengorbanan yang telah dilakukan maupun memperoleh benefit yang besar ataupun kecil, melakukan pekerjaan diimbangi dengan usaha serta kerja keras, dan memiliki komitmen yang tinggi terhadap organisasi.

\section{REFERENSI}

Bass, B. M. (1999). Two Decades of Research and Development in Transformational Leadership. European Journal of Work and Organization Psychology, 8(1), 9-32.

Basudewa, D. G. A., \& Merkusiwati, N. K. L. A. (2015). Pengaruh Locus Of Control, Komitmen Organisasi, Kinerja Auditor, Dan Turnover Intention Pada Perilaku Menyimpang Dalam Audit. E-Jurnal Akuntansi Universitas Udyana, 13(3), 944-972. https://doi.org/10.1007/BF00978448

Cook, Ellen., dan Kelley, Timothy. 1988. Management of Accounting Practices: Auditor Stress and Time Budget. The CPA Journal. 58 (7), 83-86. 
Daft, Richard L. 2011. Era Baru Manajemen. Edisi 9. (Tita Maria Kanita, Pentj). Jakarta: Salemba Empat.

Detik.com. 2018. Auditor BPKP Akui Terima Duit Dari Kemendikbud. (online) (https://news.detik.com/berita/2314690/auditor-bpkp-akui-terima-duitdari-kemendikbud, diakses tanggal 12 Juli 2018).

Deangelo, L. E. (1981). Auditor size and audit quality, 3(May), 183-199.

Devi Arista, Ni Putu dan I Wayan Ramantha. 2017. Tekanan Anggaran Waktu, Locus Of Control, Sifat Machiavellian, Pelatihan Auditor Sebagai Anteseden Perilaku Disfungsional Auditor. E-Jurnal Akuntansi Universitas Udayana.18(3), 2318-2345.

DeZoort, F.T., dan Lord, A. T. 1997. A Review and Systhesis of Pressure Effectst Research in Accounting. Journal of Accounting Literature. 1(6), 26-28.

Ghosh, D. dan Crain, T.L. 1996. Experimental Investigation of Ethical Standards and Perceived Probability on International Noncompliance. Behavioral Research in Accounting. 1(8), 79-111

Ghozali, Imam. 2016. Aplikasi Analisis Multivariate dengan Program SPSS. Semarang: Badan Penerbit Universitas Diponegoro.

Hariani, Meilinda dan Ahmad Adri. 2017. Pengaruh Locus Of Control, Turnover Intention, Kinerja Dan Komitmen Organisasi Terhadap Penerimaan Penyimpangan Perilaku Dalam Audit Pada Kantor Akuntan Publik Berafiliasi Di Dki Jakarta. Jurnal Riset Akutansi Keuangan, 2(2), 33-74.

Ivancevich, J.M., R, Konopaske, dan M.T., Matteson. 2005. Organizational Behavior and Management. Seventh Edition. McGraw-Hill Companies. Terjemahan Gina Gania. 2006. Perilaku Manajemen Organisasi. Jilid 1. Erlangga. Jakarta.

Lubis, Arfan Ikhsan. 2010. Akuntansi Keperilakuan (Edisi 2). Jakarta: Salemba Empat.

Luthans, Fred. 2011. Organizational Behavior: An Evidence-Based Approach, Twelfth Edition. New York: McGraw-Hill Company.

McNamara, S. M., \& Liyanarachchi, G. A. 2008. Time budget pressure and auditor dysfunctional behaviour within an occupational stress model. Accountancy Business and the Public Interest, 7(1), 1-43. 
O’Bryan D., Jeffrey J. Quirin, and David P. Donelly. 2005. Locus of Control and Dysfunctional Audit Behavior. Journal of Business \& Economic Research, 3(10), 1-7.

Otley, David T., dan Pierce, Bernard J. 1996. Auditor Time Budget Pressure: Consequences and Antecedents, Accounting. Auditing and Accountability Journal. 9(1), 31-58.

Rustiarini, N. W. (2014). Sifat kepribadian sebagai pemoderasi hubungan stres kerja dan perilaku disfungsional audit. Jurnal Akuntansi Dan Keuangan Indonesia, 11(1), 1-19.

Robbins, Stephen P dan Timothy A. Judge. 2015. Perilaku Organisasi. Edisi ke16. Terjemahan oleh Ratna Saraswati dan Febriella Sirait. Jakarta: Salemba Empat.

Roni, Tanjung. 2013. Pengaruh Karakteristik Personal Auditor Dan Time Budget Pressure Terhadap Perilaku Disfungsional Auditor (Studi Empiris pada KAP di Kota Padang dan Pekanbaru). Jurnal Akuntansi, 1(1), 1-22.

Sampetoding , Pricilia, Resky. 2014. Hubungan antara Time Budget Pressure, Locus of Control dan Komitmen Organisasi terhadap Perilaku Disfungsional Audit dan Pengaruhnya pada Kualitas Audit (Survey pada Auditor Perwakilan BPKP Provinsi Sulawesi Selatan). Jurnal Akuntansi, 5(1), 1-111.

Sososutiksno, Christina. 2010. Perilaku Disfungsional Akibat Tekanan Anggaran Waktu (Studi Empiris di Lingkungan Badan Pengawasan Daerah Tingkat I dan Tingkat II Provinsi Maluku). Jurnal Maksi, 10(1), 89-95.

Sugiyono. 2017. Metode Penelitian Bisnis. Bandung: PT Alfabeta.

Suprianto, Edy. 2009. Pengaruh Time Budget Pessure terhadap Perilaku Disfungsional Auditor (Audit Quality Reduction Behavior \& Underreporting of Time) (Studi Kasus pada Kantor Akuntan Publik di Jawa Tengah). Jurnal Akuntansi Indonesia, 5(1), 57-65.

Svanstrom, Tobias. 2015. Time Pressure, Training Activities and Dysfunctional Auditor Behaviour: Evidence from Small Audit Firms. International Journal of Auditing, 20(1), 42-51.

Triono, H. 2012. Pengaruh Locus of Control, Komitmen Organisasional, dan Posisi terhadap Penerimaan Perilaku Disfungsional Audit (Studi Kasus pada Kantor Akuntan Publik di Kota Semarang). Prosiding Seminar Nasional. Forum Bisnis \& Keuangan I, 152. 
ISSN: 2302-8556

E-Jurnal Akuntansi Universitas Udayana

Vol.27.2.Mei (2019): 874-898

Usmany, P. (2017). Efek Interaksi Sifat Machiavellian Dan Locus Of Control Internal Terhadap Perilaku Disfungsional Auditor, 5, 117-129.

Wahyudin, A., Anisykurlillah, I., \& Harini, D. (2011). Analisis Dysfunctional Audit Behavior: Sebuah Pendekatan Karakteristik Personal Auditor. Jurnal Dinamika Akuntansi, 3(2), 67-76.

Wintari, N. W. W. I., Sukartha, I. M., \& Badera, I. D. N. (2015). Pengaruh Tekanan Anggaran Waktu, Locus Of Control Dan Komitmen Profesional Pada Perilaku Penurunan Kualitas Audit. Jurnal Buletin Studi Ekonomi, 20(2), 138-149. 